\title{
EXAMINATION OF ANATOMICAL FEATURES OF TOMATO (LYCOPERSICON ESCULENTUM MILL.) VARIETIES CULTIVATED UNDER HYDROPONIC SYSTEM
}

\author{
TUYLU, M. \\ Department of Biology, Institute of Science, University of Süleyman Demirel, Isparta, Turkey \\ e-mail: meltemtuylu@hotmail.com \\ (Received $27^{\text {th }}$ Feb 2018; accepted $21^{\text {st }}$ May 2018)
}

\begin{abstract}
In the study it was aimed to examine and determine some anatomical features of Lycopersicon esculentum Mill. cv. Ceren and Lycopersicon esculentum Mill. cv. Panda varieties cultivated under hydroponic condition in greenhouse in Şanliurfa, Turkey. Cross sections were cut from the root, stem and leaf by microtome and examined by light microscopy. The results were photographed. Biometric measurements of some tissues were performed. The roots of the plants are surrounded by 1 layered epidermis formed by big and small cells. Vascular bundle gathered in the centre. Stems are formed 1 layered epidermis, 1-2 layered chlorenchyma, 3-4, 4-5 layered collenchyma and 3-4, 4-5 layered parenchymatic tissues. Vascular bundles are bicollateral. Pith is parenchymatic. Stomate, epidermal hair and glandular hair are observed. Leaves are bifacial and amphistomatic. Mesophyll is formed by 1 layered palisade parenchyma and 2-3 layered spongy parenchyma. Big vascular bundle is bicollateral and small vascular bundle is collateral. They have epidermal and glandular hairs. As a result, some basic anatomical features examined showed that $\mathrm{cv}$. Ceren and cv. Panda are convenient for cultivation under hydroponic system.The data obtained will contribute to soilless agricultural cultivation in the province and will pave the way for similar scientific studies.
\end{abstract}

Keywords: light microscopy, plant histology, soilless agriculture, water stress

\section{Introduction}

Greenhouse cultivation has developed related to negative developments such as climate changes and agricultural fields' abuse. In greenhouse soil and soilless agriculture can be applied depending on available irrigation and cultivation technologies. In soilless agriculture aggregate and nonaggregate (hydroponic) cultivation conditions can be used (Alan, 1990). Soilless agriculture is more productive than soil agriculture and its production cost is half of soil agriculture (Özkan, 2014).

Plant cultivation in soilless conditions is particularly developed in horticulture. It is mostly used for the cultivation of vegetable and ornamental plants. Yield can differ according to the variety of plants in cultivation using soilless agriculture techniques. For instance, while 1.25-2.5 ton $\mathrm{da}^{-1}$ tomato is cultivated in soil agriculture, $15-75$ ton $^{-1}$

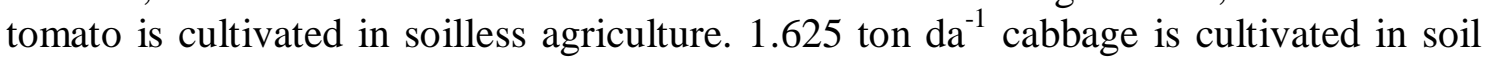
agriculture while 2.25 ton da ${ }^{-1}$ cabbage is cultivated in soilless agriculture (Alan, 2010).

Plants grow in biotic and abiotic conditions depending on their needs. These conditions may cause stress in plants. As stated in Korkmaz and Durmaz (2017) plants undergo changes in terms of quality of stress factor and genetical and ontogenic features of plants. Thus, plants adapt to factors of their environment by developing stress reactions. Stress reactions of plants exposed to stress effects can be observed when the general features of plants which are original to species are compared.

In this case not only morphological reactions of plants but also their physiological and anatomical reactions and etc. should be considered as a whole. When all these features are considered together, it can be seen if plants complete their developments and adapt to the conditions of their habitat. 
Tomato has been conventionally cultivated by using soil culture techniques. In the study, it was aimed to anatomically examine root, stem and leaf of the two varieties of tomato cultivated by using hydroponic system and to histologically specify their adaptations to the condition. Two different varieties of tomato (Lycopersicon esculentum Mill.) were randomly chosen from among varieties which are preferred cultivating in greenhouse by farmers in Turkey and were examined.

\section{Materials and methods}

The research was carried out in Şanliurfa in Southeastern Anatolia. The study area is $465 \mathrm{~m}$ above sea level and located between $37^{\circ} 08^{\prime} \mathrm{N}$ latitude and $38^{\circ} 46^{\prime} \mathrm{E}$ longitude (Demirok and Tuylu, 2017). Lycopersicon esculentum Mill. cv. Ceren (offspring F1) and cv. Panda (offspring F1) which are hybrid varieties of tomato were cultivated by using aerated deep water culture in polycarbonate covered greenhouse in Harran University, Şanllurfa, Turkey in spring in 2016 (Fig. 1). Anatomical studies were carried out in the laboratories in Ankara University, Ankara, Turkey. The data of climate belonging to 2016 and 1985-2016 long years (LY) in the province of cultivation (Anonymous, 2016) is given in Table 1, some climate values measured in the greenhouse in 2016 when the research was carried out are shown in Table 2.

Table 1. Average climate values of 2016 and 1985-2016 long years (LY) in research area (Anonymous, 2016)

\begin{tabular}{|c|c|c|c|c|c|c|c|}
\hline \multicolumn{2}{|c|}{$\begin{array}{c}\text { Climate } \\
\text { parameters }\end{array}$} & \multirow{2}{*}{$\begin{array}{c}\text { Max. } \\
\text { temperature } \\
\left({ }^{\circ} \mathbf{C}\right)\end{array}$} & \multirow{2}{*}{$\begin{array}{c}\text { Min. } \\
\text { temperature } \\
\left({ }^{\circ} \mathrm{C}\right)\end{array}$} & \multirow{2}{*}{$\begin{array}{c}\text { Ort. } \\
\text { Temperature } \\
\left({ }^{\circ} \mathbf{C}\right)\end{array}$} & \multirow{2}{*}{$\begin{array}{c}\text { Relative } \\
\text { humidity } \\
(\%)\end{array}$} & \multirow{2}{*}{$\begin{array}{l}\text { Wind } \\
\text { speed } \\
\left(2 \mathrm{~m} \mathrm{~s}^{-1}\right)\end{array}$} & \multirow{2}{*}{$\begin{array}{c}\text { Hours of } \\
\text { sunshine (h) }\end{array}$} \\
\hline Months & Year & & & & & & \\
\hline \multirow{2}{*}{ April } & 2016 & 32.7 & 7.4 & 20.6 & 36.1 & 1.4 & 8.90 \\
\hline & LY & 22.5 & 10.8 & 16.2 & 53.4 & 1.5 & 7.55 \\
\hline \multirow{2}{*}{ May } & 2016 & 35.0 & 10.7 & 23.2 & 38.3 & 1.9 & 10.20 \\
\hline & LY & 29.7 & 19.7 & 21.9 & 39.4 & 1.7 & 9.70 \\
\hline \multirow{2}{*}{ June } & 2016 & 42.0 & 18.9 & 29.8 & 28.0 & 1.9 & 11.90 \\
\hline & LY & 34.9 & 21.0 & 28.3 & 35.2 & 2.0 & 11.95 \\
\hline \multirow{2}{*}{ July } & 2016 & 43.0 & 20.9 & 33.0 & 25.4 & 1.9 & 12.40 \\
\hline & LY & 37.4 & 25.7 & 33.4 & 29.1 & 1.9 & 12.00 \\
\hline
\end{tabular}

Table 2. Some climate parameters measured in greenhouse in 2016

\begin{tabular}{c|c|c|c}
\hline Months & Decades & Temperature $^{*}\left({ }^{\circ} \mathbf{C}\right)$ & Relative humidity $^{*}(\boldsymbol{\%})$ \\
\hline \multirow{3}{*}{ April } & 2 & 23.4 & 30.6 \\
\cline { 2 - 4 } & 3 & 24.3 & 28.0 \\
\hline \multirow{3}{*}{ May } & 1 & 23.8 & 33.1 \\
\cline { 2 - 4 } & 2 & 27.9 & 30.0 \\
\cline { 2 - 4 } & 3 & 26.1 & 31.6 \\
\hline \multirow{3}{*}{ June } & 1 & 29.9 & 28.7 \\
\cline { 2 - 4 } & 2 & 31.0 & 26.8 \\
\cline { 2 - 4 } & 3 & 35.3 & 28.3 \\
\hline \multirow{3}{*}{ July } & 1 & 35.4 & 27.1 \\
\cline { 2 - 4 } & 2 & 35.8 & 28.7 \\
\hline
\end{tabular}

*Measured at 14:00 pm 


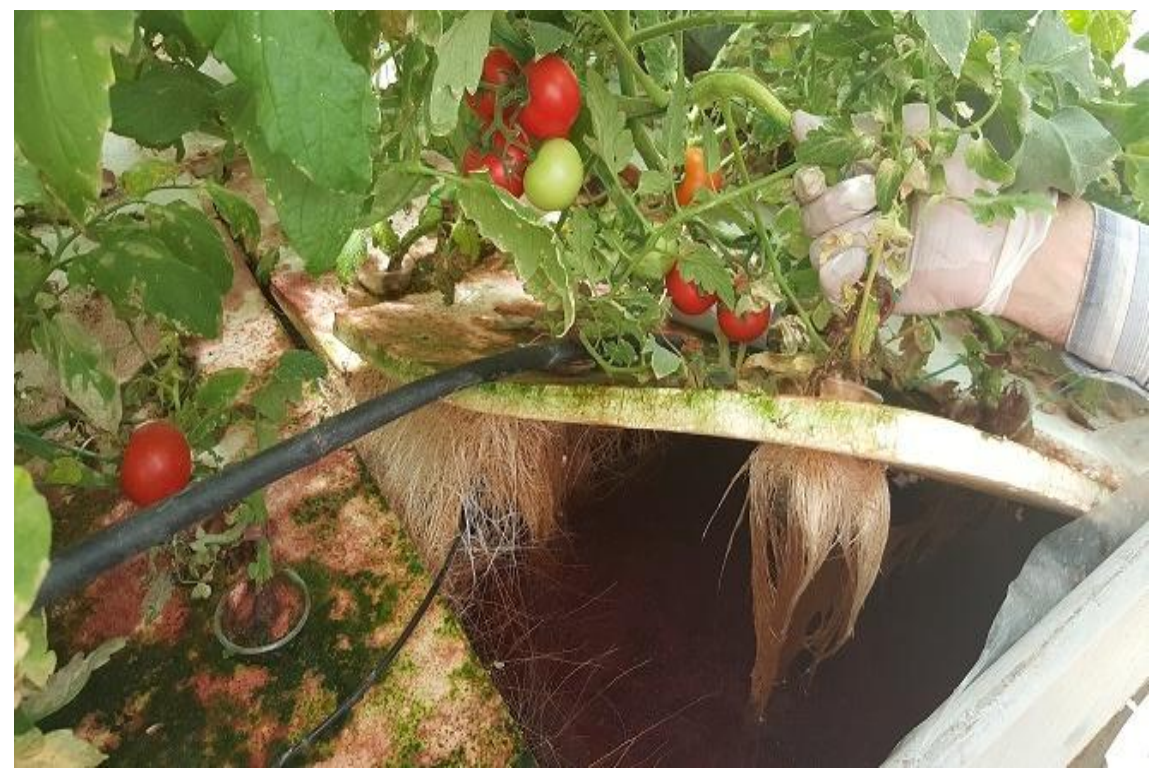

Figure 1. An appearance of hydroponic culture in greenhouse

The treatment was created as with 3 replications according to the random parcels plant pattern. Seedlings were transplanted to the hydroponic system at primary stage. 8 plants were cultivated in each basin. 2 of 8 plants cultivated were separated as border effect. Samples were taken at random from the remaining 6 plants and were observed. The basins which were made of galvanized sheet in the size of $50 \times 200 \times 30 \mathrm{~cm}$ were used for hydroponics. Nutrient solution was modified by using Arnon and Hoagland (Tuylu et al., 2018). Stock A and Stock B solutions were separately prepared (Table 3). Electrical conductivity (EC) of nutrient solution was measured as $2.5 \mathrm{dS} \mathrm{m}^{-1}$ by EC meter and $\mathrm{pH}$ of nutrient solution was set to 5.8-6.5 by using nitric acid. In soilless agriculture EC of nutrient solution has to be kept at optimum level. While high electrical conductivity (EC) reduces the yield affecting number of fruit, diameter of fruit and thickness of pericarp negatively, it causes increase of parameters of quality such as titratable acidity, amount of dry substance which is easily soluble in water, reducing glucose and lycopene (Söylemez ve Pakyürek, 2017). Air compressors were used to aerate nutrient solution used in hydroponics and nutrient solution was changed once a week. The plants were cultivated as a single stem by pruning. They were applied pesticide against diseases and pests if necessary.

Table 3. The content of element in nutrient solution ( $\left.m g l^{-1}\right)$

\begin{tabular}{c|c|c|c|c|c|c|c|c|c|c|c}
\hline \multicolumn{1}{c|}{ Stock A } & \multicolumn{3}{|c}{ Stock B } \\
\hline $\mathrm{N}$ & $\mathrm{P}$ & $\mathrm{K}$ & $\mathrm{S}$ & $\mathrm{Mg}$ & $\mathrm{Mn}$ & $\mathrm{B}$ & $\mathrm{Cu}$ & $\mathrm{Zn}$ & $\mathrm{Mo}$ & $\mathrm{Ca}$ & $\mathrm{Fe}$ \\
\hline 210 & 31 & 234 & 64 & 48 & 0.5 & 0.5 & 0.02 & 0.05 & 0.01 & 200 & 2.8 \\
\hline
\end{tabular}

The samples of plants vegetatively and generatively grown were kept in alcohol 70\% for anatomical studies. The samples of $3^{\text {rd }}$ harvest root, stem and leaf were anatomically examined from period of production including 5 harvests. Small pieces taken from lower, middle and upper parts of root, stem and leaf were dehydrated by putting them in 
different concentration series of ethanol. Then, they were saturated by paraffin. The samples were embedded in paraffin blocks to take cross sections. 8-10 $\mu \mathrm{m}$ thick cross sections from root and leaf and 20-30 $\mu \mathrm{m}$ thick cross sections from stem were taken by microtom (Leica SM 2000 R). The cross sections were stained by safranin-fast green (Algan, 1981; Tuylu et al., 2017). They were examined by light microscope (Leica 1000) and the results were photographed by digital camera (Leica EC3). The photos are completely original. Biometric measurements were performed in some tissues by using Las v4.3 program.

In the anatomical study 3 groups in itself for each replication were created. The total number of cross sections taken from the plants and examined is 90 on 9 preparats for each replication and total 270 values of measurement were obtained by taking 3 from each section. The arithmetic mean of the values of measurements and mean standard deviation were calculated by using Excel computer software and the results were commented.

\section{Results}

\section{Some anatomical features of root, stem and leaf of $c v$. Ceren and $c v$. Panda varieties}

\section{Roots}

It is observed that the general shape of cv. Ceren's root is curved. It is surrounded by one sequenced epidermis formed by large and small cells. Parenchymatic cells (cortex) between epidermis and vascular bundles have such a very thin wall that the area between epidermis and bundles looks like a large air space. It is observed that xylem vessels are big and clear and phloems are generally smaller and less than xylem vessels (Fig. $2 a, b$ and $c$ ).
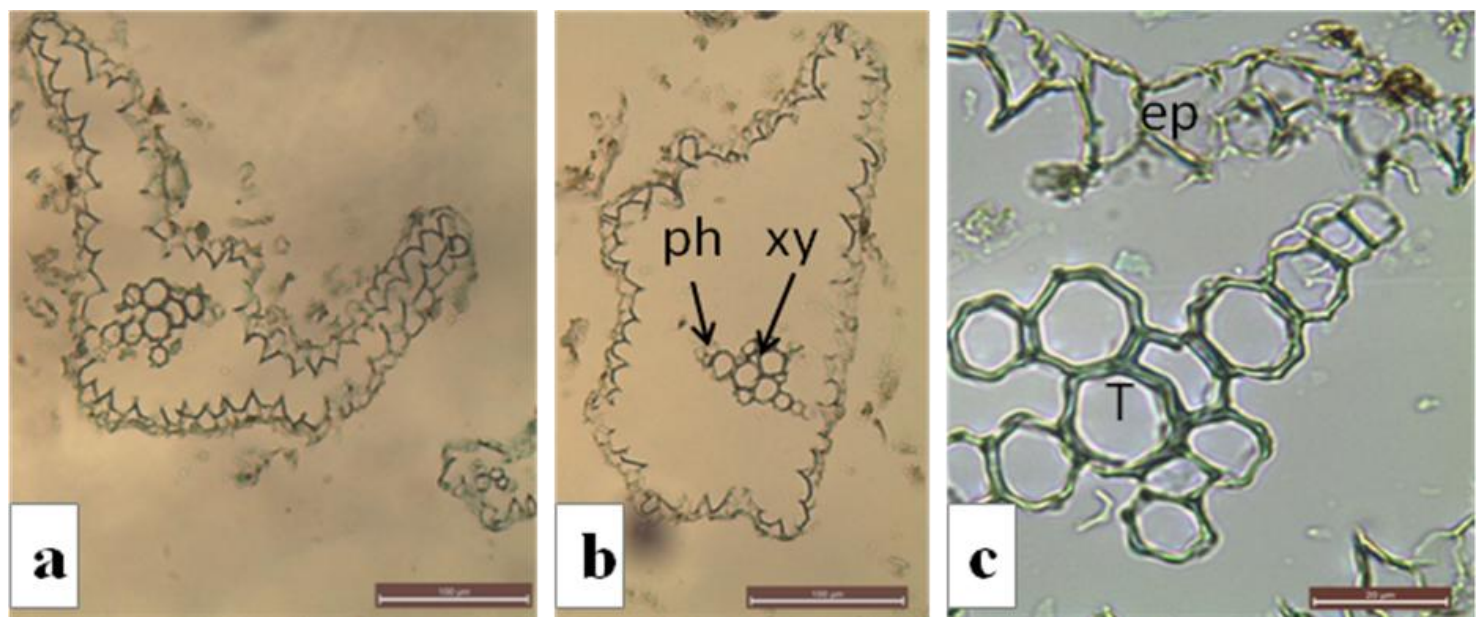

Figure 2. Root cross section in cv. Ceren. a. general shape of root, bar $=100 \mu \mathrm{m}, \mathrm{b} . x y l e m(x y)$, phloem (ph), bar $=100 \mu \mathrm{m}$, c. epidermis (ep), trachea (T), air space (as), bar $=20 \mu \mathrm{m}$

cv. Panda's root is surrounded by one layered epidermis formed by large and small cells. Endodermis and pericycle are not clearly observed. Vascular bundle is gathered in the centre (Fig. 3a and b). Parenchymatic cells (cortex) are observed between the epidermis and the vascular bundles (Fig. 3c). 

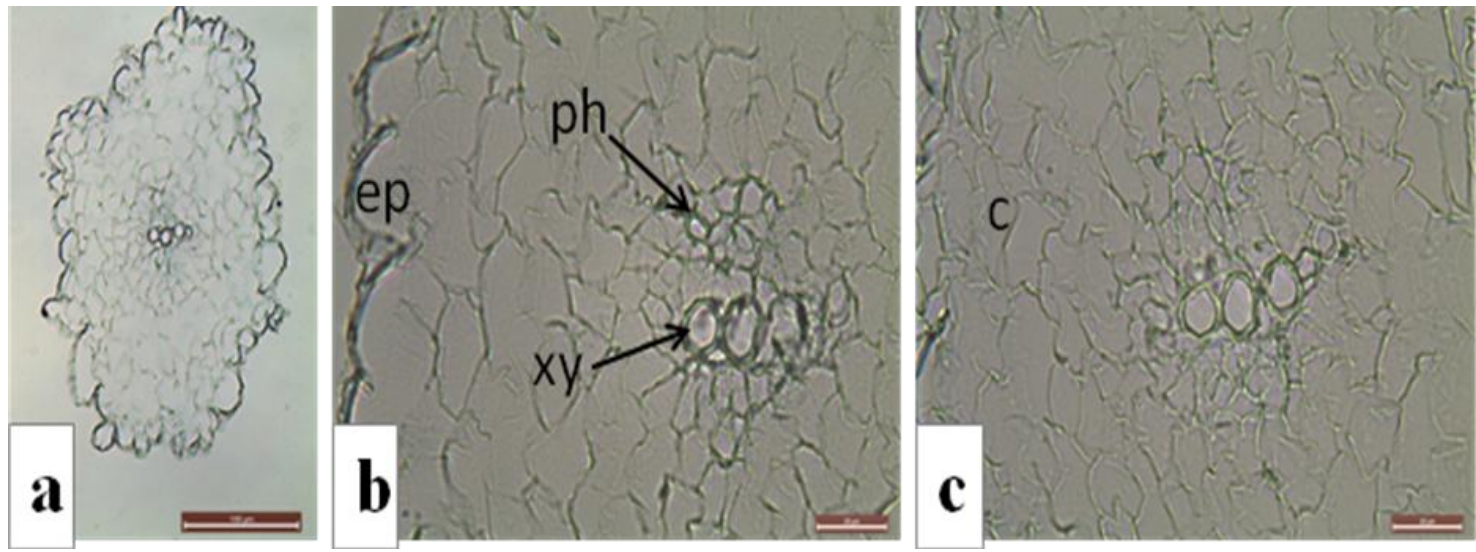

Figure 3. Root cross section in cv. Panda a. general shape of root, bar $=100 \mu \mathrm{m}$, b. epidermis (ep), xylem (xy), phloem (ph), bar $=20 \mu \mathrm{m}, \mathrm{c}$. cortex (c), bar $=20 \mu \mathrm{m}$

Biometric measurements were performed in xylem vessels in roots of two varieties. For these measurements, it was statistically determined that cv. Ceren's xylem vessels are slightly bigger than cv. Panda's xylem vessels (Table 4).

Table 4. Results of xylem vessels diameter in roots $(\mu \mathrm{m})(p<0.05)$

\begin{tabular}{c|c}
\hline Plants & Mean diameter of xylem vessels \pm std deviation \\
\hline cv. Ceren & $9.982 \pm 3.980$ \\
\hline cv. Panda & $8.059 \pm 1.721$ \\
\hline
\end{tabular}

\section{Stems}

Stomate, epidermal hair and glandular hair are observed in stem of cv. Ceren which is surrounded by one layered epidermis (Fig. $4 a, b, g, h$ and $i$ ). There are 1-2 layered chlorenchyma, 4-5 layered collenchyma and 4-5 layered parenchymatic tissue (Fig. 4a and $b$ ). Bicollateral vascular bundles surround the stem like a ring (Fig. 4c and $d$ ). 1-2 layered sclerenchyma around pholem facing in the direction of epidermis and 1-2, sometimes 3 sclerenchyma cells around phloem facing in the direction of pith are observed (Fig. 4a, $c$ and $e$ ). Pith is parenchymatic. Crystal-sands are observed in parenchymatic cells (Fig. 4f).

One layered epidermis, stomate, epidermal hair and glandular hair are observed in stem of cv. Panda (Fig. 5b, $g, h$ and $i$ ). There are 1-2 layered chlorenchyma, 3-4 layered collenchyma and 3-4 layered parenchymatic cortex (Fig. 5a). Vascular bundles surround the stem like a ring and they are bicollateral (Fig. 5a and c). 1-2 layered sclerenchyma around phloem facing in the direction of epidermis and 1-2 sclerenchyma cells around phloem facing in the direction of pith are observed (Fig. 5a, $d$ and f). Pith is parenchymatic (Fig. 5e). Crystal-sands are rarely observed in parenchymatic cells.

Biometric measurements were performed in some tissues in stems of two varieties. For these measurements, there is no clear difference between thickness of cuticle and diameter of xylem vessels of two varieties statistically. It was determined that the 
epidermis, the cortex and the collenchyma in cv. Ceren are thicker than those in cv. Panda (Table 5).
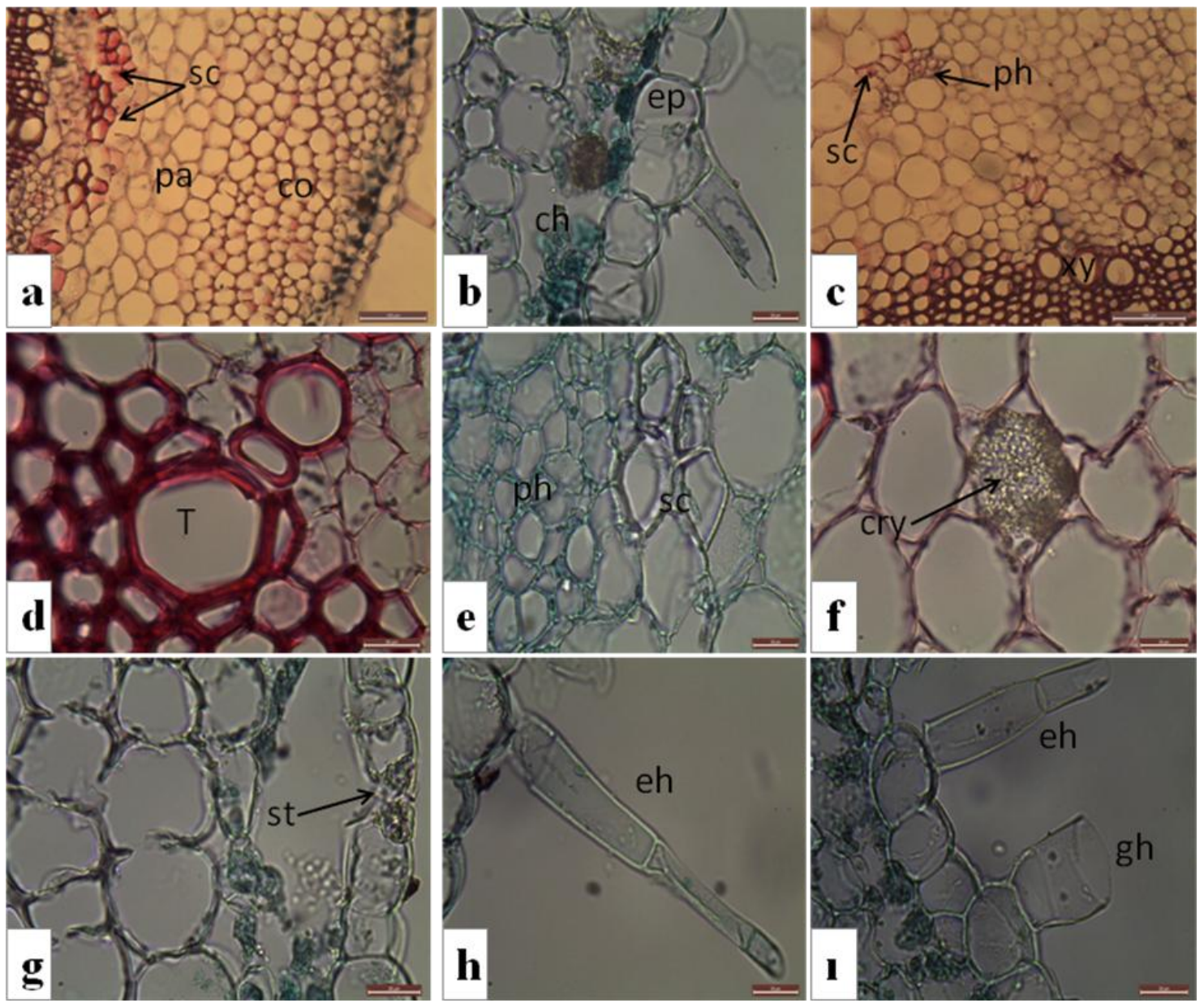

Figure 4. Stem cross section in cv. Ceren. a. collenchyma (co), parenchymous (pa), sclerenchyma (sc), bar $=100 \mu \mathrm{m}, \mathrm{b}$. epidermis (ep), chlorenchyma (ch), bar $=20 \mu \mathrm{m}, c$. sclerenchyma cells (sc), phloem (ph), xylem (xy), bar $=100 \mu \mathrm{m}, d$. trachea $(T)$, bar $=20 \mu \mathrm{m}$, e. sclerenchyma layer (sc), phloem (ph), bar $=20 \mu \mathrm{m}$, f. crystal-sand (cry), bar $=20 \mu \mathrm{m}, \mathrm{g}$. stomate (st), bar $=20 \mu \mathrm{m}$, h. epidermal hair (eh), bar $=20 \mu \mathrm{m}$, i. epidermal hair (eh), glandular hair ( $\mathrm{gh})$, bar $=20 \mu \mathrm{m}$

Table 5. Results of biometric measurements performed in some tissues of stems $(\mu \mathrm{m})$

\begin{tabular}{c|c|c|c|c}
\hline \multirow{2}{*}{ Plants } & \multicolumn{4}{|c}{ Mean biometric measurements \pm std deviation in some tissues of stems } \\
\cline { 2 - 5 } & $\begin{array}{c}\text { Thickness of } \\
\text { cuticle }^{* * *}\end{array}$ & $\begin{array}{c}\text { Thickness of } \\
\text { epidermis }\end{array}$ & $\begin{array}{c}\text { Thickness of cortex }+ \\
\text { collenchyma }\end{array}$ & $\begin{array}{c}\text { Diameter of xylem } \\
\text { vessels }^{* * *}\end{array}$ \\
\hline cv. Ceren & $1.659 \pm 0.292$ & $25.681 \pm 4.730$ & $254.789 \pm 23.388$ & $31.144 \pm 11.305$ \\
\hline cv. Panda & $1.864 \pm 0.497$ & $22.909 \pm 9.014$ & $236.890 \pm 53.503$ & $32.780 \pm 13.570$ \\
\hline
\end{tabular}

${ }^{*} \mathrm{p}<0.05,{ }^{* *} \mathrm{~ns}>0.05$ 

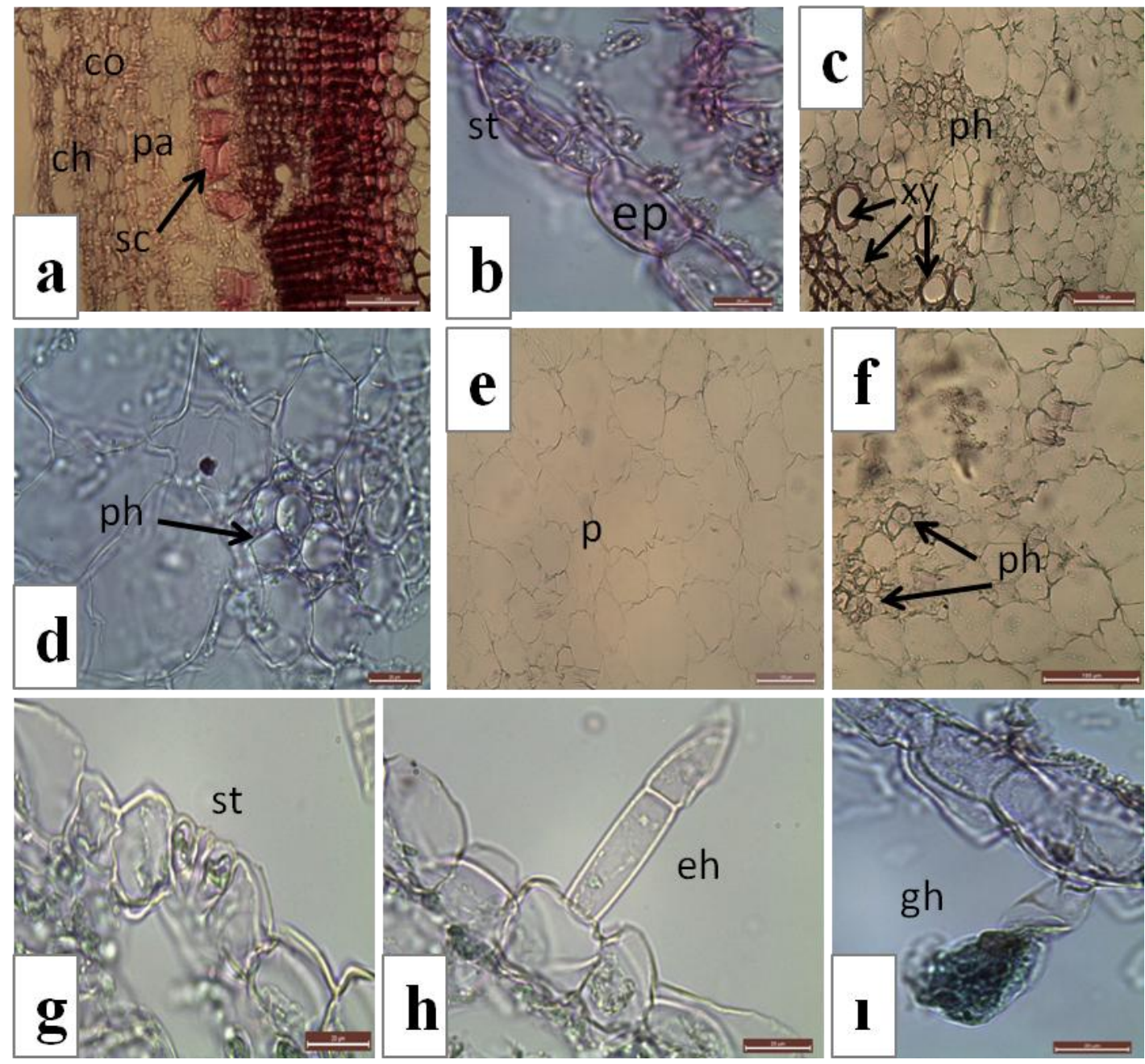

Figure 5. Stem cross section in cv. Panda a. chlorenchyma (ch), collenchymas (co), parenchymous (pa), sclerenchyma layer ( $s c)$, bar $=100 \mu \mathrm{m}, \mathrm{b}$. stomate (st), epidermis (ep), bar $=20 \mu \mathrm{m}$, c. xylem (xy), phloem (ph), bar $=100 \mu \mathrm{m}, \mathrm{d}$. phloem (ph), bar $=20 \mu \mathrm{m}$, e. pith (p), bar $=100 \mu \mathrm{m}$, f. phloem (ph), bar $=100 \mu \mathrm{m}$, g. stomate (st), bar $=20 \mu \mathrm{m}$, h. epidermal hair (ep), bar $=20 \mu \mathrm{m}, \mathrm{i}$. glandular hair (gh), bar $=20 \mu \mathrm{m}$

\section{Leaves}

cv. Ceren's leaf is bifacial (Fig. 6a). Mesophyll is formed by one layered palisade parenchyma with spaces between the cells and 2-3 layered spongy parenchyma with spaces between the cells (Fig. 6b). Big vascular bundle is bicollateral (Fig. 6c). Collateral small vascular bundles are embedded into mesophyll and surrounded by bundle sheath (Fig. $6 d$ and $e$ ). It is amphistomatic. They have glandular and epidermal hairs (Fig. $6 f$ and $g$ ). Crystal-sands are observed (Figure 6e).

cv. Panda's leaf is bifacial. Mesophyll is formed by one layered generally shortcelled palisade parenchyma with spaces between the cells and 2-3 layered spongy parenchyma with spaces between the cells (Fig. 7a). Big vascular bundle is bicollateral (Fig. $7 d$ ). Collateral small vascular bundles are embedded into mesophyll and surrounded by bundle sheath (Fig. 7b). It is amphistomatic (Fig. 7a). They have glandular and epidermal hairs (Fig. $7 e$ and f). Crystal-sands are observed (Fig. 7c). 

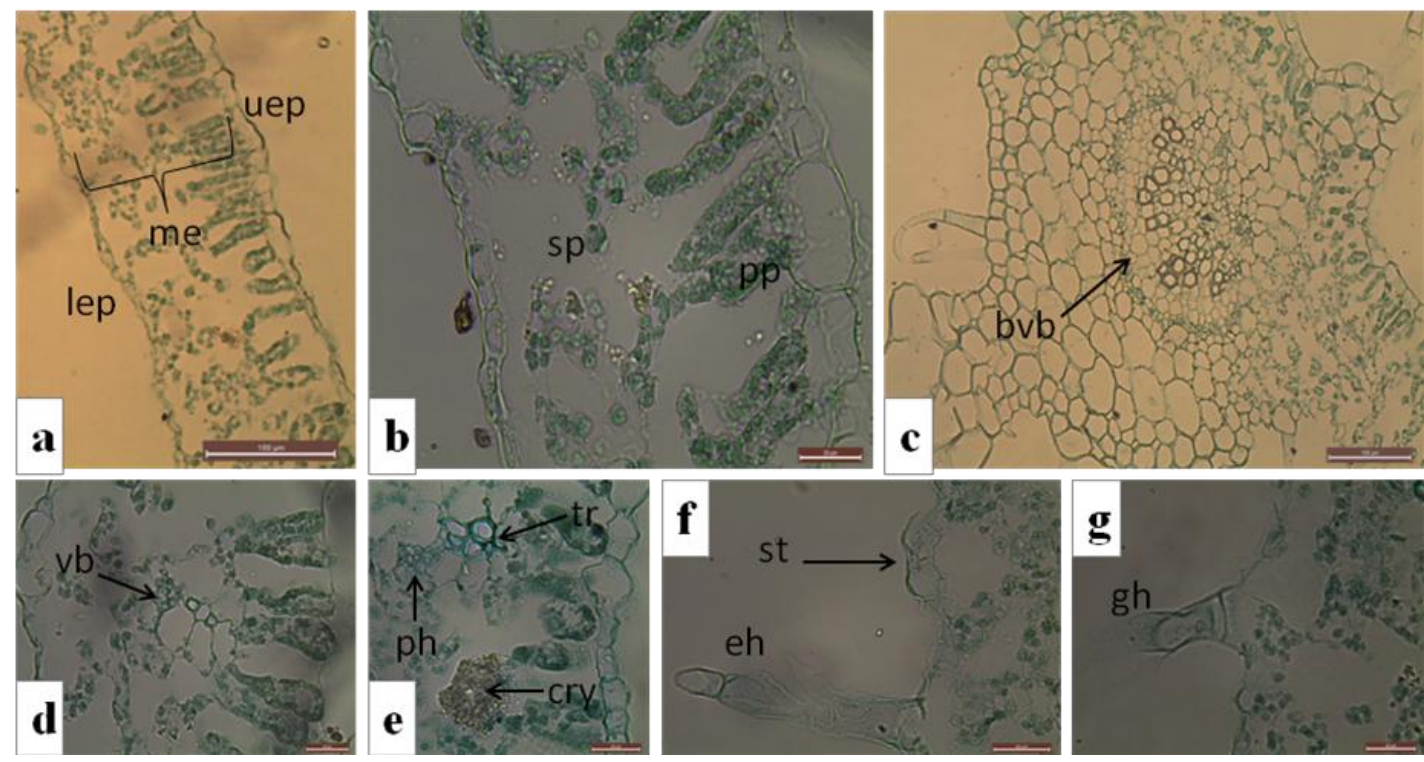

Figure 6. Leaf cross section in cv. Ceren. a. upper epidermis (uep), mesophyll (me), lower epidermis (lep), bar $=100 \mu \mathrm{m}$, b. palisade parenchyma (pp), spongy parenchyma (sp), bar $=20$ $\mu \mathrm{m}, \mathrm{c}$. big vascular bundle (bvb), bar $=100 \mu \mathrm{m}, d$. vascular bundle (vb), bar $=20 \mu \mathrm{m}, e$. phloem (ph), tracheid (tr), crystal-sand (cry), bar $=20 \mu \mathrm{m}, f$. stomate (st), epidermal hair (ep), bar $=20 \mu \mathrm{m}, \mathrm{g}$. glandular hair $(\mathrm{gh})$, bar $=20 \mu \mathrm{m}$
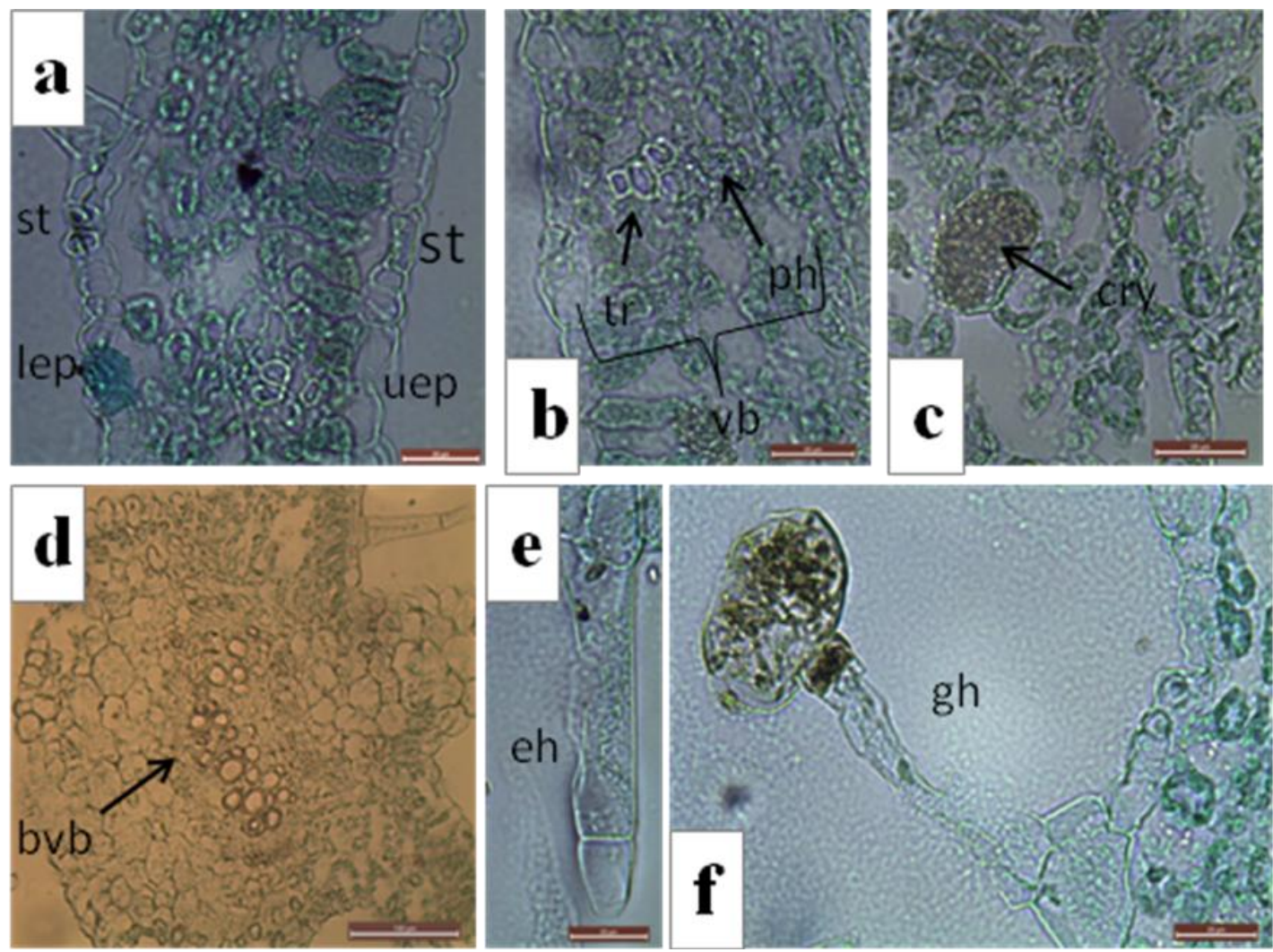

Figure 7. Leaf cross section in cv. Panda a. stomate (st), upper epidermis (uep), lower epidermis (lep), bar $=20 \mu \mathrm{m}, \mathrm{b}$. phloem (ph), tracheid (tr), vascular bundle (vb), bar $=20 \mu \mathrm{m}$, c. crystal-sand (cry), bar $=20 \mu \mathrm{m}, \mathrm{d}$. big vascular bundle (bvb), bar $=100 \mu \mathrm{m}$, e. epidermal hair (ep), bar $=20 \mu \mathrm{m}$, f. glandular hair (gh), bar $=20 \mu \mathrm{m}$ 
Biometric measurements were performed in some tissues in leaves of two varieties. These measurements showed no clear difference between mean thickness of cuticle, lower epidermis and diameter of xylem vessel of two varieties statistically.

Upper epidermis is thicker in cv. Ceren than in cv. Panda. It is determined that cv. Ceren's mesophyll is wider, and its big vascular bundle is longer than those in cv. Panda. Width of big vascular bundle in cv. Ceren is smaller than the one in cv. Panda (Table 6).

Table 6. Results of biometric measurements performed in some tissues of leaves $(\mu \mathrm{m})$

\begin{tabular}{|c|c|c|}
\hline \multirow{2}{*}{$\begin{array}{c}\text { Mean biometric measurements } \pm \text { std deviation in } \\
\text { some tissues of leaves }\end{array}$} & \multicolumn{2}{|c|}{ Plants } \\
\hline & cv. Ceren & cv. Panda \\
\hline Thickness of cuticle ${ }^{* * *}$ & $1.048 \pm 0.103$ & $1.727 \pm 0.159$ \\
\hline Thickness of upper epidermis* & $19.460 \pm 4.292$ & $13.642 \pm 3.065$ \\
\hline Thickness of lower epidermis ${ }^{* * * *}$ & $6.692 \pm 1.723$ & $8.488 \pm 2.451$ \\
\hline Width of mesophyll ${ }^{*}$ & $118.373 \pm 7.485$ & $70.830 \pm 17.463$ \\
\hline Diameter of xylem vessels ${ }^{* * *}$ & $9.066 \pm 4.742$ & $7.674 \pm 5.562$ \\
\hline $\begin{array}{l}\text { Lenght of big vascular bundle between } \\
\text { parenchymatic tissues }\end{array}$ & $159.990 \pm 16.062$ & $147.356 \pm 11.308$ \\
\hline $\begin{array}{l}\text { Width of big vascular bundle between } \\
\text { parenchymatic tissues }\end{array}$ & $263.381 \pm 7.527$ & $270.616 \pm 28.103$ \\
\hline
\end{tabular}

\section{Discussion}

The root of cv. Ceren is formed by very thin-walled parenchymatic cells between epidermis and vascular bundles and these cells could not be clearly observed. Parenchymatic cells in cv. Panda are more thick-walled than in cv. Ceren. Endodermis and pericycle could not be observed in cv. Panda either. According to Sam et al. (2000) structure and functions of all plant organs are affected by water stress. The diameters of root xylem vessels are different from each other in cv. Ceren and cv. Panda. In Tuylu et al., (2018), Malatya Kurucaova variety of tomato was examined and stated that cortex is thicker in the root cultivated in hydroponic culture and the diameters of root xylem vessels are narrower than those in the root cultivated in perlit. Regarding the two studies it is clear that cortex and xylem vessels in the root were affected by water stress.

The anatomical features in the stems and leaves examined are similar to the general anatomical features of Solanaceae family and Lycopersicon esculentum Mill. mentioned in Metcalfe and Chalk (1950) and Rost (1996). The fact that both plants have some features such as palisade parenchyma cells with spaces is the result of adaptation which they developed under water stress conditions. According to the results of mean biometric measurements in stems and leaves of cv. Ceren and cv. Panda, they adapted to the condition with histologically different sizes. The mean thickness of epidermis and mean thickness of cortex and collenchyma in stem of cv. Ceren are more than the ones in cv. Panda. Significant differences between thickness of cuticle and diameter of xylem vessel of the two varieties were not observed. In Tuylu et al. (2018) it was determined that cuticle and epidermis are thicker and cortex and xylem vessel are narrower as a 
result of water stress in the stem cultivated under hydroponic system than those cultivated in perlit condition.

According to the results of mean biometric measurements in leaves, significant differences between thickness of cuticle, lower epidermis and diameter of xylem vessels of the two varieties were not observed. The fact that in cv. Ceren upper epidermis is thicker than in cv. Panda is the result of different adaptation of the two varieties to water stress. Sam et al. (2000) studied the effects of water deficit on epidermis of leaf at preflowering stage in Lycopersicon esculentum Mill. cv. INCA9 and stated that water stress have slight effects on width and lenght of epidermis cells. Thus, it is understood that the plant also shows epidermal change under water stress as it shows under water deficit. The width of mesophyll in cv. Ceren increases more clearly than the one in cv. Panda. In parallel with this, the length of big vascular bundle in midrib region increases and its width reduces. Tuylu et al. (2018) figured out that midrib region is wider due to water stress in leaf of tomato cultivated in hydroponic system and big vascular bundles are larger than the ones cultivated in perlit condition. They stated that no clear change was measured in other tissues of leaf.

\section{Conclusion}

Considering the histological changes and biometric measurements it is understood that adaptation of cv. Ceren and cv. Panda have some differences from each other under the same cultivation conditions. According to the results it is figured out that some anatomical features such as parenchymatic cells, endodermis, pericycle, xylem vessel in root, epidermis, cortex and collenchyma in stem, upper epidermis, mesophyll, big vascular bundle in midrib region in leaf can vary from each other in terms of histologically thickness, width, length, arrangement of cells and etc. in the two different varieties belonging to the same genus cultivated at the same time and under the same condition.

In the study, the two varieties could grow in alternative condition which is out of their natural cultivation condition and it was observed that they could complete their developments in some basic tissues. In this cultivation the roots of plants were exposed to excess water, but both plants adapted to water stress condition and developed by means of some anatomical changes. In both plants no clear anomaly was observed. cv. Ceren and cv. Panda are convenient for cultivation under hydroponic culture mentioned in terms of some basic anatomical features examined. However; features of fruit of the plants should be evaluated in terms of parameters of yield and quality before recommending the producers to cultivate the two varieties under hydroponics. In addition, in the study the anatomical features of the two varieties determined will contribute to other studies.

\section{REFERENCES}

[1] Alan, R. (1990): Some cultivation conditions and their features used in greenhouse (Serada Kullanılan Bazı Yetiştirme Ortamları ve Özellikleri). - Türkiye 5. Seracılık Sempozyumu, pp. 401-410, İzmir.

[2] Alan, R. (2010): The place and importance of hidroponic culture in vegetable cultivation (Sebze Yetiştiriciliğinde Su Kültürünün Yeri ve Önemi). - Atatürk Üniversitesi Ziraat 
Fakültesi Dergisi 14(1-2). http://dergipark.gov.tr/ataunizfd/issue/2993/41509\#article_cite (Accessed on: 19.10.2017).

[3] Algan, G. (1981): Microtechnology for Plant Tissues (Bitkisel Dokular İçin Mikroteknik). - Fırat Üniversitesi Yayınları, Botanik No. 1, Elazığ.

[4] Anonymous (2016): Şanlıurfa Climate Values (Şanlıurfa İklim değerleri). - Regional Directorate of Meteorology Data Base (Meteoroloji Bölge Müdürlüğü Veri Tabanı), Şanlıurfa, Turkey (personally received).

[5] Demirok, A., Tuylu, G. I. (2017): Evaluation of planning and actual irrigation time scheduling for the maize (Zea mays L.) plant in Harran Plain (Harran Ovası'nda Misır Bitkisi (Zea mays L.) için Planlanan ve Gerçekleşen Sulama Zamanı Programının Değerlendirilmesi). - Harran Tarım ve Gıda Bilimleri Dergisi 21(1): 84-90.

[6] Korkmaz, H., Durmaz, A. (2017): Responses of Plants to Abiotic Stress Factors (Bitkilerin Abiyotik Stres Faktörlerine Verdiği Cevaplar). - GUFBED 7(2): 192-207.

[7] Metcalfe, C. R., Chalk, L. (1950): Anatomy of the Dicotyledons. Vol. II, pp. 965-978. Clarendon Press, Oxford.

[8] Özkan, Ş. (2014): soilless agricultural production. Current and future situation of soilless agricultural products in 2012-2013 cultivated in the Mediterranean region of Turkey. A Study on "tomato and strawberry" (Topraksız Tarım Üretimi, 2012-2013 Yıllarında Türkiye'nin Akdeniz Bölgesi’nde Gelişmekte Olan "Topraksız" Tarım Ürünlerinin Bugünkü Durumu ve Gelecekle İlgili Tahminler, Domates ve Çilek Üretimi Üzerine Bir Araştırma). - Giresun Üniversitesi Sosyal Bilimler Enstitüsü-Yüksek Lisans Tezi, Giresun.

[9] Rost, T. L. (1996): Tomato Anatomy. - Section of Plant Biology, Division of Biological Sciences, University of California, Davis. http://wwwplb.ucdavis.edu/labs/rost/Tomato/tomhome.html (accessed on: 17.10.2017).

[10] Sam, O., Jerez, E., Dell'Amico, J., Ruiz Sanchez, M. C. (2000): Water stress induced changes in anatomy of tomato leaf epidermis. - Biologia Plantarum 43(2): 275-277.

[11] Söylemez S., Pakyürek A. Y. (2017): Responses of rootstocks to nutrient induced high ec levels on yield and fruit quality of grafted tomato cultivars in greenhouse conditions. Applied Ecology and Environmental Research 15(3): 759-770.

[12] Tuylu, M., Büyükkartal, H. N., Akgül, G., Kalyoncu, H. (2017): Comparing stem and leaf anatomy of Marrubium lutescens Boiss. and M. cephalanthum Boiss. \& Noë subsp. akdaghicum (Lamiaceae) (Marrubium lutescens Boiss. ve M. cephalanthum Boiss. \& Noë subsp. Akdaghicum (Lamiaceae)' un Gövde ve Yaprak Özelliklerinin Anatomik Olarak Karşılaştırılması). - Süleyman Demirel Üniversitesi Fen Bilimleri Enstitüsü Dergisi 21(1): 113-117.

[13] Tuylu, M., Tuylu, G. İ., Söylemez, S., Büyükkartal, H. N. (2018): Comparing some anatomical features of tomato (Lycopersicon esculentum Mill. cv. Kurucaova) cultivated under perlit and hydroponic culture (Perlit ve Su Kültürü Ortamlarında Yetiştirilen Domates (Lycopersicon esculentum Mill. cv. Kurucaova) Bitkisinin Bazı Anatomik Özelliklerinin Karşılaştırılması). - Süleyman Demirel Üniversitesi Fen Bilimleri Enstitüsü Dergisi. DOI: 10.19113/sdufbed.93255. 